\title{
GENERALIZED STEFFENSEN'S INEQUALITY BY MONTGOMERY IDENTITIES AND GREEN FUNCTIONS
}

\author{
ASFAND FAHAD AND JOSIP PEČARIĆ
}

Abstract. A new generalization of Steffensen's inequality and other inequalities related to Steffnesen's inequality have been proved. The contribution of these new generalizations has been presented to theory of $(n+1)$-convex functions and exponentially convex functions.

Mathematics subject classification (2010): Primary 26D10, 26D15, Secondary 26D20.

Keywords and phrases: Steffensen's inequality, Green's function, Montgomery's identity, $(n+1)$ convex function at a point.

\section{REFERENCES}

[1] N. I. AkHIEZER, The Classical Moment Problem and Some Related Questions in Analysis, Oliver and Boyd, Edinburgh, (1965).

[2] S. N. Bernstein, Sur les fonctions absolument monotones, Acta Math. 52, (1929), 1-66.

[3] A. FAhad, J. PeČArić And M. Praljak, Generalized Steffensen's Inequaliy, J. Math. Inequal. 9, 2 (2015), no. 2, 481-487.

[4] A. FAhad, J. PeČarić And M. Praljak, Hermite Interpolation of Composition Function and Steffensen-type Inequalities, J. Math. Inequal. 10, (2016), no. 4, 1051-1062.

[5] A. FAHAD, J. PEČARIĆ AND M. I. QuRESHI, Generalized Steffensen's Inequaliy by Lidstone Interpolation and Montgomery's Identity, J. Inequal. Appl. 237 (2018).

[6] E. Hewitt And K. Stromberg, Real and abstract analysis, 3rd edition, Springer, New York, 1975.

[7] J. JAKŠEtić, J. PeČARIĆ, Exponential Convexity method, J. Convex Anal. 20, 1 (2013), 181-187.

[8] N. Mehmood, R. P. Agarwal, S. I. Butt and J. PeČarić, New Generalizations of Popoviciutype inequalities via new Green's functions and Montgomery identity, J. Inequal. Appl. 2017, 1 (2017), 108.

[9] J. PEČARIĆ, Connections among some inequalities of Gauss, Steffensen and Ostrowski, Southeast Asian Bull. Math. 13, 2 (1989), 89-91.

[10] J. PeČARIĆ, M. PRALJAK AND A. WitKowsKi, Linear operator inequality for $n$-convex functions at a point, Math. Inequal. Appl. 18 (2015), 1201-1217.

[11] J. Pečarić, F. Proschan and Y. L. Tong, Convex functions, Partial Orderings and Statistical Applications, Academic Press, New York, 1992.

[12] J. PeČarić, K. Smoljak Kalamir And S. Varošanec, Steffensen's and related inequalities (A comprehensive survey and recent advances), Monographs in inequalities 7, Element, Zagreb, 2014.

[13] P. RABIER, Steffensen's inequality and $L^{1}-L^{\infty}$ estimates of weighted integrals, Proc. Amer. Math. Soc. 140, 2 (2012), 665-675.

[14] J. F. STEFFENSEN, On certain inequalities between mean values, and their application to actuarial problems, Skand. Aktuarietidskr. 1 (1918), 82-97. 